\title{
KARAKTER RABBANI SEBAGAI MEDIUM PEMBENTUKAN KECERDASAN SPIRITUAL DALAM PROSES PEMBELAJARAN \\ (Sebuah Analisis Empiris pada SDIT Kota Palopo)
}

\author{
Sitti Amrah \\ SMP Negeri 2 Palopo Kota Palopo Prov. Sulawesi Selatan \\ Email: amrahrahmuddin@gmail.com
}

\begin{abstract}
Rabbani's character emphasizes the functionalization of Godliness in the learning process through spiritual values, honesty, sincerity, compassion, tolerance, discipline, hard work, creative, independent, democratic, communicative and prioritizes emphasis on affective aspects (heart). Rabbanicharacterhas positive implications for fostering spiritual intelligence in the education process. The purpose of maximizing Rabbani character education in the context of learning is to actualize the potential of spirituality possessed by students, fostering sensitivity and religious responsibility of students through exemplary values, habituation, advice, warnings and punishments. Efforts to apply Rabbani character education in fostering spiritual intelligence can be initiated through the development of religious education curricula, familiarizing Islamic values, creating a cool and beautiful school environment, and applying disciplinary values in the learning process. The method used in the study is descriptive-analytical with interview methods to get maximum results.
\end{abstract}

Keywords: Rabbani character, spiritual intelligence, religious culture.

\section{Pendahuluan}

Telah banyak dibicarakan bahwa krisis yang menimpa manusia modern saat ini adalah krisis yang bersifat kompleks dan multidimensi di mana segi-seginya menyentuh setiap aspek kehidupan. Krisis ini merupakan krisis dalam dimensi-dimensi intelektual, moral, dan spiritual. Fritjof Capra (1984: 21), A. Qodri Azizy (2003: 214), Masdar Helmy (2008: 124) dan Umar Sulaiman (2017: 8) berpendapat bahwa berbagai krisis tersebut, termasuk krisis spiritual, belum pernah terjadi sebelumnya dalam catatan sejarah umat manusia krisis-krisis itu banyak bersentuhan dengan krisis spiritual (spiritual crisis). Pandangan senada diungkapkan oleh Danah Zohar dan Ian Marshal (2000: 8) dan Peter Bayer (1994: 15), bahwa era ini ditandai oleh munculnya krisis mendasar pada 
masyarakat modern saat ini. Krisis semacam ini oleh Daniel Goleman (1995: 334) dan Nurcholish Madjid (1998: 156) menyebutkan bahwa tahun-tahun terakhir milenium ini memperkenalkan "zaman kemurungan" (age of melancholy), seperti halnya abad XXI menjadi "abad kecemasan" (the age of anxienty). Data internasional memperlihatkan apa yang tampaknya merupakan wabah depresi modern, wabah yang meluas seiring dengan diterimanya gaya hidup modern di seluruh dunia. Danah Zohar dan Ian Marshall (2000: 18) menganggap budaya modern ini secara spiritual bodoh (spiritually dumb); tidak hanya di Barat, tetapi juga di negara-negara Asia yang semakin terpengaruh oleh Barat. Oleh karena itu, manusia modern, dalam pandangan Hossein Nasr (1975: 4) sedang berada di wilayah pinggiran eksistensinya, dan bergerak menjauhi pusat dirinya. Sedangkan pusat atau esensi dirinya itu bersifat spiritual. Kondisi ini juga dicemaskan oleh Arnold J. Toynbee (1956: 97-98) bahwa di era ini, setidaknya muncul ada dua hal yang melanda manusia modern dewasa ini, yaitu kosongnya jiwa dari nilai-nilai spiritual dan tegarnya dimensi materialistis pada kehidupan mereka. Atau sebaliknya, dengan lebih dominan aspek spiritual dan melepaskan aspek material.

Krisis modern yang kini mengejala sehingga menyebabkan lahirnya proyek liberalisasi, rasionalisasi dan efisiensi, menurut Azyumardi Azra (1998: 100), berpotensi melakukan proses pendangkalan kehidupan spiritual. Liberalisasi yang terjadi pada seluruh aspek kehidupan tak lain adalah proses desakralisasi dan despiritualisasi tata nilai kehidupan. Dalam proses semacam itu, agama yang sarat dengan nilai-nilai sakral dan spiritual, perlahan tapi pasti, terus tergusur dari berbagai aspek kehidupan masyarakat. Kadang-kadang agama dipandang tidak relevan dan signifikan lagi dalam kehidupan. Akibatnya, sebagaimana terlihat pada gejala umum masyarakat modern, kehidupan rohani semakin kering dan dangkal. Di sisin yang lain, kemajuan sains yang hanya mengandalkan kecerdasan rasio, sampai pada batas-batas tertentu, akan dapat mengerosikan benteng-benteng nilai idealisme humanisme dan semakin menuju ke arah rasionalisme, sekularistik sehingga melahirkan aliran sekularisme.

\section{Merespon kenyataan problematik ini, maka $\mathrm{p}$ a $\mathrm{r}$ a d i g m a} Pendidikan perlu direkonstruksi ulang agar nilai-nilai yang terkandung di dalamnya tidak mengalami disorientasi atau kehilangan peran-peran normatif yang menjadi basis epistimologisnya. Pendidikan yang menekankan nilai-nilai normatif harus dibangun atas dasar pengembangan potensi manusia menuju pembentukan pribadi manusia yang utuh. Hal ini sejalan dengan makna esensial pendidikan Islam sebagai sebuah upaya untuk memelihara dan mengembangkan fitrah manusia serta sumber daya insani menuju 
terbentuknya manusia seutuhnya sesuai dengan norma Islam. Asumsi ini menyiratkan akan adanya posisi sentral manusia dalam pendidikan. Pendidikan yang menekankan pada aspek nilai-nilai kemanusian, yang disebut dengan gerakan humanisasi pendidikan. Dalam perspektif pendidikan Islam, humanisasi tidak sekedar diartikan kesadaran akan realitas aktual, tetapi juga mencakup kesadaran terhadap diri pribadi sebagai manusia yang sesungguhnya memiliki jati diri yang utuh. Manusia yang sesungguhnya adalah manusia yang mampu mengaktualkan potensi fitrahnya sehingga dapat mewujudkan dirinya sebagai pengembang amanah Tuhan sebagai khalifah di muka bumi.

Menjawab tantangan krisis yang dialami masyarakat modern, maka pola pendidikan yang berorientasi pada pembentukan karakter Rabbani yang sesuai dengan nilai-nilai moral keagamaan adalah salah satu alternatif yang tepat agar ruh pendidikan tidak kehilangan dimensi epistimologis dan aksiologisnya. Dimensi epistimologis dan aksiologis pendidikan menurut hemat penulis adalah proses pendidikan yang bertujuan mengaktualkan potensi para peserta didik sesuai dengan fitrah hanifnya sebagai manusia teomorfis. Dengan demikian, hakikat manusia teomorfis manusia yang mampu mengaktualkan potensi Spiritual Quotient (kecerdasan spiritual). Spiritual Quotient adalah kecerdasan untuk menghadapi persoalan makna (value) yaitu kecerdasan untuk menempatkan perilaku dan hidup seseorang dalam kontek makna yang lebih luas dan kaya. Menurut Danah Zohar dan Ian Marshall (2000: 8) Spiritual Quotient adalah landasan yang diperlukan untuk mengfungsikan Intelligence Quotient dan Emotional Quotient secara efektif. Di sisi lain, Spiritual Quotient memungkinkan seseorang untuk menyatukan hal-hal yang bersifat intrapersonal dan interpersonal, serta menjembatani kesenjangan antara diri dan orang lain. Dengan kata lain, seseorang yang memiliki kecerdasan spiritual memiliki kepribadian yang bertumpu pada nilai-nilai insaniah kemanusiaan yang memancarkan cahaya ruhiah yang menerangi sikap dan tingkah lakunya maupun perbuatannya sehingaga tampil sebagai manusia hanif (lurus), optimis dan konsisten dan bermanfaat bagi lingkungan sekitarnya.

Berdasarkan penelitian dilakukan penulis, menunjukkan bahwa strategi penerapan kecerdasan spiritual dalam membentuk karakter Rabbani para peserta didik memperlihatkan gejala dan indikator yang cukup signifikan pada Sekolah Dasar Islam Terpadu (SDIT) Madani Palopo, yang mana nilai-nilai pendidikan telah menjadi habit yang terus ditumbuhkembangkan dalam desain kurikulum dan satu pengajaran. Namun, ditemukan persoalan krusial yang membutuhkan antisipasi segera, antara lain, yaitu: pertama, tidak semua siswa berasal dari lingkungan keluarga yang harmonis. Ada di 
antara mereka yang orang tuanya broken home, atau orang tuanya bermasalah yang dapat menimbulkankegaduhan danberimplikasipada absensi, keterlambatan, pembangkangan, tidak mengerjakan tugas, tidur di kelas dan menyontek. Kedua, lingkungan keluarga yang kondusif dapat menjaga kesinambungan penerapan pendidikan karakter yang dilaksnakan di satuan-satuan pendidikan. Sebaliknya, lingkungan keluarga yang bermasalah, dapat menyebabkan terkendalanya upaya sosialisasi dan internalisasi nilainilai pendidikan karakter kepada peserta didik, dan ketiga, belum maksimalnya peran orang tua dalam mendukung penerapan pendidikan karakter di lingkungan sekolah, serta masih terbatasnya sarana dan prasarana dalam mendukung penerapan pendidikan karakter di masing-masing satuan pendidikan.

\section{Metode Penelitian}

Metode yang digunakan pada penelitian ini bersifat kualitatif. Pendekatan yang digunakan adalah pendekatan filosofis-normatif, sosiologis dan antropologis. Teknik pengumpulan data dalam penelitian ini adalah wawancara. Adapun analisis data adalah proses mencari dan menyusun secara sistematis data yang diperoleh dari wawancara, catatan lapangan, dan dokumentasi dengan cara mengorganisasikan data ke dalam kategori, menjabarkan dalam unit-unit, melakukan sintesa, menyusun ke dalam pola, memilih mana yang penting dan yang akan dipelajari, dan membuat kesimpulan sehingga mudah dipahami oleh diri sendiri maupun orang lain.

\section{Pembahasan dan Analisis}

\section{Konsep Karakter Rabbani dan Kecerdasan Spiritual}

Term karakter Rabbani (Ibn Faris Zakariyahm 1399: 329) dan padanannya selalu berorientasi pada pembentukan perilaku manusia yang mulia dan terpuji. Karakter atau akhlak menurut Ibn Miskawaih (1398: 25) dan Imam Al-Ghazali (2004: 70) adalah sikap mental yang mengandung daya dorong untuk berbuat tanpa berpikir dan pertimbangan yang matang. Sikap mental terbagi dua, yaitu yang berasal dari watak dan berasal dari kebiasaan dan latihan. Akhlak yang berasal dari watak jarang menghasilkan akhlak yang terpuji; kebanyakan akhlak yang jelek. Sedangkan latihan dan pembiasaan lebih dapat menghasilkan akhlak yang terpuji. Karena itu Ibn Miskawaih sangat menekankan pentingnya pendidikan untuk membentuk akhlak yang baik. Dia memberikan perhatian penting pada masa kanak-kanak, yang menurutnya merupakan mata rantai antara jiwa hewan dengan jiwa manusia. 
Menurut Tadzkiratun Musfiroh, (Sofan Amir, 2011: 13) karakter mengacu pada serangkaian sikap (attitude), perilaku (behavior), motivasi (motivation) dan ketrampilan (skiil). Dengan demikian, karakter adalah sifat-sifat kejiwaan, akhlak atau budi pekerti yang membedakan seseorang dari yang lain, tabiat atau watak. Budi merupakan alat bantu yang merupakan panduan akal dan perasaan untuk menimbang baik buruk tabiat, akhlak, watak perbuatan baik, daya upaya dan akal. Dalam konteks yang lain, Ki Hadjar Dewantara (1962: 25) menyebut karakter itu dengan nama budi pekerti atau watak, pikiran dan tubuh anak.

Orang yang telah mempunyai kecerdasan budi pekerti itu senantiasa memikirmikirkan dan merasa-rasakan serta selalu memakai ukuran, timbangan dan dasar-dasar yang pasti dan tetap. Itulah sebabnya tiap-tiap orang itu dapat kita kenal wataknya dengan pasti, yaitu karena watak atau budi pekerti itu memang bersifat tetap dan pasti buat satu-satunya manusia sehingga dapat dibedakan orang yang satu dari pada yang lain. Pendidikan budi pekerti, tidak hanya bermanfaat kepada yang dididik saja, bermanfaat pula kepada orang yang ada disekelilingnya. Kehalusan budi pekerti peserta didik, akan bermanfaat bagi guru di sekolah, bagi kawan-kawannya, bagi keluarganya dan masyarakat. Dengan demikian Ki Hadjar Dewantara menilai bahwa pengajaran budi pekerti sangat perlu bahkan wajib kepada siswa agar mereka menjadi anak yang bersusila, berkepribadian dan berkarakter. Lebih lanjut Ki Hajar Dewantara, memandang karakter itu sebagai watak atau budi pekerti. Lebih lanjut dikatakan budi pekerti adalah bersatunya antara gerakan, fikiran dan perasaan dan kehendak atau kemauan yang kemudian menimbulkan tenaga. Secara ringkas, tokoh pendidikan nasional ini menjelaskan karakter adalah sebagai sifatnya manusia, mulai dari angan-angan hingga terjelma menjadi tenaga. Dengan adanya budi pekerti, manusia akan menjadi pribadi yang merdeka sekaligus berkepribadian mulia dan dapat mengendalikan diri sendiri.

Matthew Davidson dan Thomas Lickona (2006: 24) secara geniun menjelaskan, bahwa pendidikan karakter mendukung pencapaian kualitas akademik melalui penyediaan lingkungan religius. Peserta didik harus merasa aman, kompeten, dan percaya diri, ketika berada pada lingkungan tersebut. Lingkungan religius dapat diperoleh melalui proses pendidikan yang menanamkan nilai-nilai religi. Nilai religi sebaiknya ditanamkan sedini mungkin agar dapat membangkitkan gairah spiritual anak. Hal itu disebabkan kualitas spiritual yang tertanam dalam jiwa peserta didik, sedikit banyak akan memberi kontribusi terhadap pencapaian kualitas karakter. Dengan demikian, prilaku peserta didik selalu mengarah kepada perbuatan baik. Ikhtiar untuk 
membentuk siswa yang bermoral Thomas Lickona (1991: 51) menjelaskan, bahwa pendidikan karakter tidak hanya mengajarkan mana yang baik dan mana yang tidak baik. Pendidikan karakter berusaha menanamkan kebiasaan mengenai hal yang baik sehingga para siswa dapat memahami, mampu merasakan, dan mau melakukan perbuatan baik. Perilaku baik dari peserta didik mencerminkan keberhasilan dari pendidikan karakter. Secara filosofis pendidikan karakter sangat berpedoman pada inti nilai etika, seperti kepedulian, kejujuran, keadilan, tanggung jawab, serta menghormati diri sendiri dan orang lain. Islam memiliki pendidik yang baik dan ideal. Makna semacam ini menurut Muhammad Imarah (1972: 80) sinkron dengan tujuan pendidikan agama yakni mendidik jiwa dan akal sehingga manusia bisa mendapatkan kebahagiaan dunia akhirat. Dalam ujran lain Azyumardi Azra (2006: 176) mengatakan bahwa pendidikan agama tidak hanya menanamkan nilai-nilai keimanan dan ketaqwaan an sich, akan tetapi harus memiliki tujuan untuk mengembangkan kualitas karakter dan kualitas intelektual. Di sisi lain, pendidikan agama masih dipandang dapat memberi kontribusi terhadap perkembangan karakter peserta didik karena melihat banyak bukti mengenai penurunan moral pelajar, seperti seringnya pelajar melakukan hal-hal yang tidak baik. Pembentukan dan pendidikan karakter melalui lembaga pendidikan merupakan suatu usaha yang sangat mulia. Sekolah bukan hanya mendidik peserta didik untuk unggul dalam ilmu pengetahuan dan teknologi, melainkan juga handal dalam karakter dan kepribadian. Untuk mencapai hal itu, dibutuhkan pendidikan pembinaan yang serius dalam membentuk peserta didik yang memiliki karakter religious.

Berdasarkan analisis diatas, maka pendidikan karakter Rabbani adalah pendidikan yang menekankan fungsionalisasi sifat-sifat Ketuhanan dalam proses pembelajaran melalui nilai-nilai spiritual, kejujuran, keikhlasan, kasih sayang, toleran, disiplin, kerja keras, kreatif, mandiri, demokratis, komunikatif dan lebih mengutamakan penekanan pada aspek afektif (hati). Karena pendidikan menekankan pada locus hati, meniscayakan munculnya pengembangan nilai-nilai sikap, etika, kepercayaan, perasaan dan moral. Pendidikan afektif (hati) dapat mendorong para siswa memiliki kecerdasan emosional dan sekaligus kecerdasan intelektual sehingga mereka dapat memperluas pemahaman mengenai ajaran-ajaran agamanya, mendorong mereka untuk mengamalkannya, membentuk akhlak serta kepribadiannya sesuai tujuan pendidikan Islam. Hal ini dalam pandangan Wina Sanjaya (2010: 272) dimungkinkan karena domain afektif adalah kawasan yang berkaitan dengan aspek-aspek emosional, seperti: perasaan, minat, sikap, kepatuhan terhadap moral dan sebagainya, yang dilakukan melalui proses pembentukan 
nilai sehingga para siswa dapat berperilaku sesuai dengan norma-norma yang berlaku di dalam masyarakat.

Upaya menumbuh-kembangkan karakter Rabbani di lingkungan pendidikan secara diametral akan melahirkan kecerdasan spiritual. Pandangan ini sejalan Taufik Pasiak (2003: 27) Spiritual Quotient beroperasi dari pusat otak yaitu dari fungsi-fungsi penyatu otak, ia adalah bagian terdalam dan terpenting manusia. Dan secara saintifik Spiritual Quotient terletak pada Neuroanatomi dan Neurokimia membuktikan bahwa Spiritual Quotient itu berbasis pada otak manusia . Basis itu adalah (1) Osilasi $40 \mathrm{~Hz}$, (2) Penanda Somatik, (3) Bawah sadar Kognitif, (4 )God Spot. Keempat variabel melukiskan kesatuan kerja jaringan syaraf yang menyatukan kepingan-kepingan pengalaman menjadi sesuatu yang utuh mereka menjadi substrat penting kehadirat Tuhan. Spiritual Quotient dibangun atas teori "God Spot" (Titik Tuhan). God spot merupakan sekumpulan saraf yang terletak di daerah lobus temporal otak dibalik pelipis. God spot berfungsi menyadarkan akan eksistensi fundamental yang menyebabkan kita bersikap idealistis dan mencari solusi atas problem yang ada. God spot membuat kita berhasrat pada sesuatu yang lebih tinggi (transenden), sehingga muncul rasa cinta yang mendalam, rasa damai yang mendalam, rasa kesatuan eksistensi, dan keindahan yang mendalam.

Adapun ciri-ciri Spiritual Quotient (Akhirin, 2013: 16) yang dapat berkembang dengan baik mencakup hal-hal berikut: 1) Kemampuan bersikap fleksibel (adaptif secara spontan dan aktif); 2) Tingkat kesadaran yang tinggi; 3) Kemampuan untuk menghadapi dan memanfaatkan penderitaan; 4) Kemampuan untuk menghadapi dan melampaui rasa sakit; 5) Kualitas hidup yang diilhami oleh visi dan nilai-nilai; 6) Keengganan untuk menyebabkan kerugian yang tidak perlu; 7) Kecenderungan untuk melihat keterkaitan antara berbagai hal (berpandangan holistik); 8) Kecenderungan untuk bertanya "mengapa" atau "bagaimana jika" untuk mencari jawaban-jawaban yang mendasar; 9) Menjadi apa yang disebut psikolog sebagai bidang mandiri yaitu memiliki kemudahan untuk melawan konvensi.

\section{Strategi Pembentukan Karakter Rabbani dalam Membangun Kecerdasan Spiritual}

Kecenderungan pola pembelajaran pendidikan karakter Rabbani yang lebih mengutamakan pada proses transmisi knowledge an sich, menimbulkan kekhawatiran dan kecemasan yang dapat menimbulkan kesenjangan-kesenjangan out put yang akan dihasilkan oleh lembaga pendidikan. Menurut Muhaimin (2009: 106) bahwa proses pembelajaran pendidikan agama Islam di sekolah lebih bersifat verbalistik dan formalistik 
atau merupakan tempelan saja. Metodologi dari dulu sampai sekarang tidak kunjung berubah padahal masyarakat yang dihadapi sudah banyak mengalami perubahan. Pendekatan pendidikan agama Islam cenderung normatif tanpa dibarengi ilustrasi konteks sosial budaya sehingga peserta didik kurang menghayati nilai-nilai agama sebagai nilai yang hidup dalam keseharian. Sistem evaluasi, bentuk soal-soal ujian agama Islam menunjukan prioritas pada kognitif, jarang pertanyaannya mempunyai bobot nilai dan makna spiritual keagamaan yang fungsional dalam kehidupan sehari-hari. Oleh karena sejatinya pendidikan adalah suatu proses dalam rangka mempengaruhi peserta didik agar dapat menyesuaikan diri sebaik mungkin terhadap lingkungannya dan dengan demikian akan menimbulkan perubahan dalam dirinya yang memungkinkannya untuk berfungsi secara dekat dalam kehidupan masyarakat.

Upaya menumbuhkan pendidikan karakter Rabbani yang berbasis Spiritual Quotient dapat diinisiasi melalui pengembangan budaya keagamaan di lingkungan pendidikan. Dalam konteks pengembangan budaya keagamaan dan penanaman pendidikan karakter di lingkungan sekolah, Lynne Broadbent dan Alan Brown (2002: 176), secara lugas mengakui bahwa pendidikan akan membutuhkan relevansi dengan konteks budaya siswa. Hal ini membutuhkan pengembangan keilmuan dan pemahaman terhadap agama masyarakat yang ada di sekitarnya yang mewakili secara nasional. Dalam konteks ini, kontribusi pendidikan agama terhadap pengembangan sosial budaya adalah melalui kunjungan-kunjungan ke tempat peribadatan dan mengakhiri pertikaian dengan penganut komunitas daerah yang telah terdaftar dalam relasi kebangsaan. Mendukung argumentasi ini, Jose Luis Martinez Lopes Muniz (2006: 307) menaruh harapan untuk mempromosikan toleransi, pendidikan agama harus dapat menyerap jauh ke dalam iman dan kepribadian yang dimiliki peserta didik terhadap keyakinan dan perasaan orang lain serta terhadap ritual dan praktek keseharian. Dalam posisi semacam ini, penting bagi manusia untuk memahami sesuatu yang menjadi bagian dari budaya dan pengalaman agama secara luas. Hal ini sejalan dengan Roland S. Barth (2002: 7) bahwa pengembangan budaya keagamaan di sekolah memiliki pengaruh yang lebih jauh terhadap kehidupan siswa dan proses belajar di sekolah, terhadap kebijakan departemen pendidikan, bagi pengawas, dewan sekolah dan bahkan kepala sekolah.

Pengembangan budaya keagamaan di lingkungan sekolah dapat dilakukan dengan metode yakni prescriptive dan learning process (secara terprogram) terhadap suatu masalah. Pertama, adalah pembentukan budaya keagamaan sekolah melalui penurutan, penganutan dan penataan terhadap suatu skenario (tradisi perintah). Kedua, adalah 
pembentukan budaya keagamaan secara terprogram atau Learning process. Adapun strategi yang dilakukan oleh para praktisi pendidikan untuk membentuk budaya keagaman di sekolah, melalui; pertama, tauladan atau contoh, kedua, membiasakan hal-hal yang baik, ketiga, menegakkan disiplin, keempat, memberikan motivasi atau dorongan, kelima, memberikan hadiah terutama psikologis, keenam, hukuman, dan ketujuh. penciptaan suasana religius bagi para siswa.

Dalam tataran praktik keseharian nilai-nilai keagamaan yang telah disepakati diwujudkan dengan bentuk sikap dan prilaku keseharian oleh semua warga sekolah. Proses pengembangan tersebut dalam dilakukan melalui tiga tahap yaitu: Pertama, sosialisasi nilai-nilai agama yang disepakati sebagai sikap dan perilaku ideal yang ingin dicapai pada masa mendatang disekolah. Kedua, adalah penetapan action plan mingguan atau bulanan sebagi tahapan dan langkah sistematis yang dilakukan oleh semua pihak sekolah dalam mewujudkan nilai-nilai agama yang telah disepakati tersebut. Ketiga, yakni pemberian pengahargaan terhadap prestasi warga sekolah seperti guru, tenaga kependidikan atau peserta didik sebagai usaha pembiasaan yang menjunjung sikap dan perilaku yang komitmen dan loyal terhadap ajaran dan nilai-nilai yang disepakati.

Menurut Ngainum Naim (2009: 17) terdapat beberapa metode untuk menanamkan nilai-nilai budaya keagamaan di lingkungan sekolah. Pertama, yakni dengan pengembangan budaya religius sekolah yang rutin dilaksanakan disetiap hari dalam pembelajaran. Kedua, yakni menciptakan lingkungan lembaga pendidikan yang mendukung dan dapat menjadi laboratorium bagi penyampaian pendidikan agama. Lingkungan dalam konteks pendidikan memang memiliki peranan yang signifikan dalam pemahaman dan penanaman nilai. Suasana lingkungan lembaga pendidikan dapat menumbuhkanreligius culture. Ketiga, pendidikan agama tidak hanya disampaikan secara formal dalam pembelajaran dengan materi pelajaran agama, namun juga dapat dilakukan diluar proses pembelajaran. Keempat, menciptakan situasi keadaan religius. Tujuannya adalah untuk mengenalkan kepada peserta didik tentang pengertian dan tata cara pelaksanaan agama dalam kehidupan sehari-hari. Kelima, memberikan kesempatan kepada para siswa untuk mengekspresikan diri, menumbuhkan bakat, minat, dan kreativitas pendidikan agama dalam ketrampilan dan seni seperti membaca al-Qur'an dengan lagu , membaca asmaul husna, adzan, sari tilawah, dan lain sebagainya. Keenam, menyelenggarakan berbagai macam perlombaan seperti cerdas cermat untuk membiasakan dan melatih keberanian, kecepatan, dan ketepatan menyampaikan pengetahuan dan mempraktikkan materi pendidikan Islam. Ketujuh, diselenggarakannya 
aktivitas seni, seperti seni suara, seni musik atau seni tari. Seni adalah sesuatu yang berarti dan relevan dalam kehidupan. menentukan kepekaan peserta didik dalam memberikan ekspresi dan tanggapan dalam kehidupan, seperti kemampuan akademisi, sosial, emosional, budaya, moral, dan kemampuan pribadinya untuk pengembangan spiritual.

\section{Penerapan Model Karakter Rabbani dalam Membentuk Kecerdasan Spiritual Siswa SDIT Insan Madani Kota Palopo}

Ikhtiar untuk mengetahui penerapan model karakter Rabbani dalam membentuk kecerdasan spiritual siswa di SDIT Insan Madani Kota Palopo, maka terdapat beberapa variabel yang turut mempengaruhi dan memberikan andil dalam proses pembelajaran, di antaranya visi dan misi SDIT Insan Madani Kota Palopo, kinerja Kepala Sekolah, bentuk-bentuk karakter Rabbani yang diterapkan dalam upaya membentuk kecerdasan spiritual, faktor pendukung dan penghambat penerapan karakter Rabbani, pola kerjasama antara Kepala Sekolah, guru, dan masyarakat, serta berbagai faktor-faktor lainnya. Analisis tentang penerapan bentuk karakter Rabbani dalam membentuk kecerdasan spiritual siswa di SDIT Insan Madani Kota Palopo, dengan menggunakan metode wawancara melalui uraian yang bersifat deskriptif.

Secara normatif visi dan misi yang diemban oleh Sekolah Dasar Islam Terpadu (SDIT) Insani Madani Kota Palopo, sejak berdirinya memiliki visi "mencetak generasi Rabbani melalui pendidikan yang unggul, bermutu dan Islami". Adapun misi yang diembannya, antara lain; Mewujudkan nilai Islam melalui penyelenggaraan sekolah . a) melakukan Islamisasi dalam isi dan proses pembelajaran, b) melaksanakan layanan pendidikan secara adil dan memuaskan, c) melakukan pemberdayaan SDM secara berjenjang dan berkesinambungan, d) melakukan pembelajaran yang aktif, kreatif, efektif dan menyenangkan, e) melakukan pembimbingan secara komprehensip dengan orientasi terbentuknya akhlak yang mulia, f) melakukan penggalian dan pengembangan bakat secara terprogram, dan g) memberikan penghargaan kepada guru dan karyawan berdasarkan prestasi.

Fungsionalisasi visi dan misi Sekolah Dasar Islam Terpadu (SDIT) Insani Madani Kota Palopo dilakukan melalui beberapa upaya, sebagai berikut; 1) Pemberdayaan peran serta masyarakat, orang tua peserta didik, dan dunia usaha sekitar sekolah untuk mempercepat peningkatan mutu dan relevansi pendidikan. 2) Mendorong motivasi, sikap dan perilaku masyarakat dan orang tua peserta didik yang bertanggungjawab, agar 
kebutuhan dan harapan akan kualitas pendidikan dapat terpenuhi. 3) Meningkatkan peran serta Komite Sekolah, agar lebih meningkatkan perannya sebagai mitra sekolah. 4) Meningkatkan dan memberdayakan semua anasir Sekolah Dasar Islam Terpadu (SDIT) Insani Madani Kota Palopo agar mampu meningkatkan profesionalitas pendidik. 5) Memotivasi dewan guru agar mampu berinovasi dalam mendidik agar kegiatan mengajar menarik dan menyenangkan, dan 6) Meningkatkan kegiatankegiatan yang bersifat religius dan nasionalis agar terjalin silturahmi yang baik. Muatan visi dan misi ini secara operasional dikemas dalam proses pembelajaran di Sekolah Dasar Islam Terpadu (SDIT) Insani Madani Kota Palopo sehingga memungkinkan para siswa dapat belajar sambil berbuat (learning by doing) melalui pembiasaan dengan menanamkan pendidikan karakter Rabbani dalam bentuk akhlak al-karimah dalam lingkungan akademis, keluarga maupun di tengah-tengah kehidupan masyarakat sehubungan dengan penanaman karakter Rabbani sebagai basis upaya menumbuhkan Spiritual Quotientdi Sekolah Dasar Islam Terpadu (SDIT) Insani Madani Kota Palopo, menurut Basaruddin (Kepala Sekolah) dengan menggunakan dua acara sebagaimana di atas dengan menekankan pada aspek-aspek rabbaniyah dan insaniah yakni membumikan nilai-nilai ketuhanan dan nilai-nilai kemanusian melalui program-program unggulan yang telah ditetapkan. Sehubungan dengan program-program unggulan tersebut, peneliti ketika melakukan penelitian di Sekolah Dasar Islam Terpadu (SDIT) Insani Madani Kota Palopo ditemukan fakta bahwa pengembangan dan pelaksanaan budaya keagamaan yang berlangsung di Sekolah Dasar Islam Terpadu (SDIT) Insani Madani Kota Palopo sudah nampak pada kehidupan warga sekolah.

Ritual rabbaniyah (nilai-nilai Ketuhanan) yang dibudayakan di lingkungan Sekolah Dasar Islam Terpadu (SDIT) Insani Madani Kota Palopo yang berkontribusi terhadap tumbuhnya pendidikan akhlak atau karakter yang bersifat islami adalah membudayakan salam sesama warga sekolah, sholat secara berjamaah sesuai jadwal yang telah ditetapkan, sholat dzuhur berjamaah di akhiri dengan kultum, kewajiban berbusana Muslimah bagi siswi, pemeliharaan kebersihan lingkungan, kegiatan pesantren kilat, budaya infak dan sedekah bagi guru dan siswa setiap hari jumat, pelaksanaan kegiatan peringatan hari besar Islam, di sekolah ini diterapkan muatan lokal Tuntas Baca Tulis Al-Quran (TBTQ), kegiatan ekstra kurikuler yakn (Qasidah) dan santunan kepada kaum dhu'afa (fakir miskin dan yatim).

Sedangkan ritual kemanusian yang dibudayakan di Sekolah Dasar Islam Terpadu (SDIT) Insani Madani Kota Palopo, antara lain; tata tertib sekolah, budaya jujur, kerja 
keras, upacara bendera, lomba kebersihan kelas, kegiatan pengumpulan infaq dan sedekah, pengumpulan bantuan sosial bagi korban bencana, kunjungan ke panti-panti asuhan, maupun kegiatan-kegiatan sosial yang sifatnya suka rela dan tidak memaksa. Bentuk-bentuk pendidikan karakter Rabbani yang dikembangkan di Sekolah Dasar Islam Terpadu (SDIT) Insani Madani Kota Palopo, antara lain;

Pertama, pembudayaan akhlak islami (Budaya Salam) Salam merupakan salah satu bentuk pemberian motivasi yang sangat berarti dalam sebuah hubungan agar dapat meningkatkan semangat dalam kehidupan, baik hubungan kekeluargaan, persahabatan, dan lain sebagainya. Urgensi salam dan kontribusinya bagi kehidupan sosial dan upaya penerapannya di Sekolah Dasar Islam Terpadu (SDIT) Insani Madani Kota Palopo dengan ucapan sapa dan salam sambil bersalaman dan mencium tangan para gurunya. Hal ini biasanya dilakukan siswa saat datang dan pulang sekolah. Bahkan dari pengamatan penulis, kebiasaan salam juga dilakukan di saat-saat tertentu; jam istirahat misalnya, ketika bertemu guru atau pembina penyelenggara sekolah, siswa selalu menyapa dengan ucapan salam disertai mencium tangan. Dan dampak psikologis dari kebiasaan membudayakan salam ini semakin mempererat hubungan antara Kepala Sekolah, para guru, staf karyawan, maupun dengan para siswa.

Kedua, berdoa sebelum dan sesudah belajar setiap kali melakukan pekerjaan sangat dianjurkan dalam Islam untuk berdoa, baik itu dilakukan sebelum atau sesudah pekerjaan/kegiatan. Doa dipandang sebagai otaknya ibadah karena ia suatu ibadah yang terang sekali dan memperlihatkan penghambaan kepada Allah SWT. Sedang menurut istilah doa berarti memohon kepada Allah SWT secara langsung untuk memperoleh karunia dan segala yang diridhoiNya dan untuk menjauhkan diri dari kejahatan atau bencana yang tidak dikehendakinya. Dalam konteks kegiatan di sekolah, siswa Sekolah Dasar Islam Terpadu (SDIT) Insani Madani Kota Palopo sudah terbiasa berdoa sebelum dan sesudah melakukan kegiatan belajar, kebiasaan ini sudah menjadi budaya bagi siswa. Membiasakan para siswa untuk berdoa sebelum dan sesudah belajar merupakan salah satu upaya untuk memberikan pembelajaran kepada para siswa, bukan hanya sebatas pada ranah kognitif, tetapi bisa menyentuh sampai ke ranah afektif dan psikomotorik. Upaya untuk mewujudkan budaya berdoa ini Kepala Sekolah dan guru selalu memberikan motivasi kepada peserta didik agar selalu berdoa, dan guru diharapkan menjadi tauladan bagi siswa. 
Ketiga, membudayakan shalat berjamaah para warga sekolah shalat berjamaah adalah shalat yang dilakukan oleh dua orang atau lebih secara bersama-sama, salah seorang bertindak sebagai imam dan yang lainnya sebagai makmum. Shalat berjamah mengajarkan kepada manusia agar hidup dalam kebersamaan. Hidup bersama merupakan salah satu ketentuan alam yang Allah ciptakan dalam kehidupan ini. Manusia butuh komunikasi satu sama lain, ia merasa kehidupannya berarti karena ada orang lain yang hadir disisinya. Disaat berprestasi ada orang lain yang mengapresiasinya dan saat lengah tentu ada orang lain juga yang mengingatkannya.

Beberapa pesan edukatif yang terkandung dalam perintah shalat berjamaah inilah yang selalu diterapkan di lingkungan Sekolah Dasar Islam Terpadu (SDIT) Insani Madani Kota Palopo untuk membangun dan memupuk kebersamaan antara siswa dengan para guru dan warga sekolah lainnya. Menurut Siti Sumardiyah bahwa kebiasaan melakukan shalat secara berjamaah telah berjalan secara kontinu dengan melibatkan seseorang komponen sekolah. Tradisi ini shalat berjamaah biasanya juga dilanjutkan dengan kultum (kuliah tujuh menit) yang disampaikan oleh para guru maupun pimpinan sekolah lainnya, yang jadwalnya telah dibuat secara bergiliran. Suasana semacam ini, selain dapat menumbuhkan semangat keagamaan para siswa, juga dijadikan sebagai media untuk membangun silaturrahim yang kompak, harmonis dan penuh kekeluargaan dengan sesama warga sekolah.

Keempat, meberikan santunan kepada anak yatim dan kaum dhu'afa secara periodic Salah satu kegiatan ekstrakurikuler yang berpretensi menumbuhkan rasa solidaritas dan empati sosial yang sering dilakukan keluarga besar Sekolah Dasar Islam Terpadu (SDIT) Insani Madani Kota Palopo adalah memberikan santunan kepada anak yatim dan kaum dhu'afa melakukan pengumpulan sumbangan, baik berupa uang maupun pakaian dari warga sekolah. Menurut Ida Alam Nur, kegiatan sosial semacam ini sering dilakukan oleh warga sekolah sebagai bentuk tanggung jawab sosial terhadap lingkungan sekitarnya. Kegiatan ini biasanya dilakukan bersamaan dengan peringatan hari-hari besar Islam dan Nasional, seperti peringatan maulid Nabi Muhammad SAW, hari raya Idul Fitri, peringatan HUT Kemerdekaan RI atau Milad Sekolah Dasar Islam Terpadu (SDIT) Insani Madani Kota Palopo. Adapun teknik pengumpulan dan mekanisme penyalurannya biasanya dikoordinir langsung oleh Wakasek Kesiswaan dan dibantu oleh para guru pendidikan agama Islam. Adapun sasaran pemberian santunan ini, biasanya diberikan kepada siswa-siswi Sekolah Dasar Islam Terpadu (SDIT) Insani Madani Kota Palopo yang telah menjadi yatim piatu atau secara ekonomi masih jauh 
dari kecukupan. Di samping itu, santunan ini langsung diberikan kepada panti-panti asuhan yang khusus menampung para yatim piatu dan kaum dhu'afa.

Kelima, peringatan hari-hari besar keagamaan kegiatan Peringatan Hari Besar Islam (PHBI) adalah kegiatan ekstra kurikuler yang memiliki kontribusi sebagai media dakwah dan syiar Islam. Tujuan dan maksud diadakan peringatan hari-hari besar Islam adalah menggali dan menangkap pesan-pesan moral keagamaan yang selanjutnya dapat diterapkan dalam kegiatan proses belajar mengajar di lingkungan Sekolah Dasar Islam Terpadu (SDIT) Insani Madani Kota Palopo. Hal ini dijelakan oleh Imran Khalid, bahwa tujuan esensial yang terkandung dalam peringatan hari-hari besar Islam adalah mengajarkan kepada para siswa tentang kisah-kisah teladan dan edukatif dari setiap peristiwaan keagamaan yang dilaksanakan. Di sisi lain, dengan dibudayakannya peringatan hari-hari besar Islam setiap tahun dapat memberikan perspektif yang komprehenship tentang nilai-nilai ajaran Islam kepada para siswa sehingga mereka terlibat secara emosional dan merasa bahwa nilai-nilai ajaran Islam amat berguna bagi kehidupan mereka. Dan untuk menambah semangat dan khidmat peringatan hari-hari besar Islam ini, momentum ini biasanya diisi dengan kegiatan-kegiatan lain, seperti lomba pentas seni Islam yang meliputi: puisi Islami, adzan dan sholat, dan lomba nasyid atau qasidah ala Islam.

Keenam, mengadakan pesantren kilat dan buka puasa bersama pesantren kilat adalah kegiatan pesantren yang dilaksanakan pada saat bulan ramadhan, disebut juga pesantren ramadhan.Biasanya dilaksankan selama empat hari, di awal atau di akhir bulan ramadhan.Program/kegiatan pesantren kilat adalah salah satu kegiatan ekstrakurikuler pendidikan agama Islam dan rohani Islam dalam rangka pembinaan keimanan dan ketakwaan kepada Allah SWT dengan metode pesantren yang dilakukan dalam lingkungan sekolah atau di luar sekolah dalam waktu yang singkat, disesuaikan dengan jadwal serta kebutuhan sekolah. Penyelenggaraan pesantren kilat bertujuan untuk menambah wawasan keislaman siswa di sekolah. Materi pembelajaran diarahkan untuk memperdalam materi pendidikan agama Islam yang selama di dalam kelas kurang luas dan terkesan dibatasi. Selain itu, siswa diarahkan untuk mampu mempraktekkan langsung hasil belajar selama ini, seperti sholat fardhu berjamaah, sholat dhuha, membaca al-Qur'an, dan i'tikaf.

Adapun kurikulum pesantren kilat mengacu kepada pendalaman materi pendidikan agama Islam pada aspek aqidah, fiqih dan tarikh.Adapun tujuan utama 
dari kegiatan Sanlat adalah: (1) Memperdalam, memantapkan dan meningkatkan pemahaman dan penghayatan ajaran agama Islam bagi peserta didik; (2) Menerapkan dan mengamalkan ajaran agama Islam dalam kehidupan sehari-hari dalam rangka membentuk mental spiritual peserta didik yang tangguh, mandiri dan memiliki kepribadian Muslim yang kokoh agar mampu menghadapi tantangan negatif dari pengaruh luar diri peserta didik.

Ketujuh, mengembangkan program tuntas baca tulis Al-Quran tuntas Baca Tulis aql-Quran adalah kegiatan khusus yang dilakukan oleh sekolah di luar jam pelajaran dalam rangka mendidik, membimbing, dan melatih keterampilan membaca, menulis, menghafal, dan memahami arti al-Quran, khususnya bagi peserta didik yang belum memiliki kompetensi membaca dan menulis al-Quran. Kegiatan ini dilaksanakan setiap hari sabtu dibawah pengawasan langsung guru-guru pendidikan agama Islam. Kegiatan ini bertujuan agar para siswa dapat memahami isi kandungan al-Qur'an, dan menumbuhkan kecintaan terhadap al-Qur'an sehingga dapat dijadikan bacaan yang dapat mengasah pengetahuan agama para siswa. Selain membaca a kl-Qur'an, juga dijelaskan kandungan makna dan kisah yang terkandung di dalamnya agar para siswa memiliki pengetahuan yang luas tentang Al-Qur'an sehingga mempraktekkan dalam kehidupan sehari-hari, baik di lingkungan sekolah maupun di tengah-tengah kehidupan masyarakat luas.

Program baca tulis Al-Qur'an merupakan ini salah program unggulan Sekolah Dasar Islam Terpadu (SDIT) Insani Madani Kota Palopo yang sifatnya wajib diikuti oleh siswa karena termasuk pelajaran muatan lokal (mulok). Kegiatan ini dilaksanakan oleh tidak hanya guru pendidikan agama Islam akan tetapi melibatkan seluruh guru umum. Artinya, setiap hari Sabtu semua kelas selama 2 jam pelajaran bagi siswa Muslim wajib untuk mengikuti BTQ. Program ini selain mampu meningkatkan kemampuan membaca al- Qur'an, juga berpengaruh terhadap pengembangan rasa spiritual dan moral/akhlak siswa.Setidaknya siswa lebih tenang, mudah menerima nasehat, dan selalu semangat mengikuti pelajaran.

Kedelapan, menyelenggarakan malam bina iman dan takwa (Mabit) kegiatan malam bina iman dan takwa ini merupakan yang bersifat indidentil, namun bersifat wajib yang biasanya dilakukan setahun sekali. Waktunya pelaksanaanya setiap hari Sabtu yang dimulai dari 17.00 sampai Ahad pagi. Setiap siswa yang hadir diabsen untuk diketahui tingkat partisipasinya. Jenis-jenis kegiatan malam bina iman dan takwa 
menurut Siti Sumardiyah, antara lain; ceramah agama, zikir bersama, sholat malam, kajian fiqh al-Nisa, olahraga sehat sambil bersalawat. Kegiatan-kegiatan ini sangat diminati para siswa karena dapat menambah wawasan pengetahuan mereka terhadap nilai-nilai ajaran Islam.

Rangkaian kegiatan yang dapat menumbuhkan karakter Rabbani di Sekolah Dasar Islam Terpadu (SDIT) Insani Madani Kota Palopo, mengindikasikan bahwa proses pembelajaran dan pembudayaan nilai-nilai pendidikan agama mengalami peningkatan yang signifikan. Keberhasilan ini karena ditunjang oleh strategi dan program yang telah tersusun. Startegi mencakup cara-cara yang ditempuh sedangkan program menyangkut kegiatan operasional yang perlu dilakukan. Strategi dan program merupakan dua hal yang selalu berkaitan. Selain itu Untuk membudayakan nilai-nilai ajaran agama Islam dapat dilakukan dengan beberapa cara, antara lain melalui kebijakan pimpinan sekolah, pelaksanaan kegiatan belajar mengajar di kelas, kegiatan ekstrakurikuler di luar kelas serta tradisi dan perilaku warga sekolah secara kontinyu dan konsisten, sehingga tercipta budaya Islami tersebut dalam lingkungan sekolah.

Berdasarkan uraian dan analisis tentang pengembangan budaya keagamaan yang dilakukan Kepala Sekolah Dasar Islam Terpadu (SDIT) Insani Madani Kota Palopo, memberikan beberapa implikasi positif terhadap pembentukan karakter Rabbani para siswa, antara lain shalat fardhu para siswa dilaksanakan secara teratur, kemampuan baca tulis Al-Quran mengalami peningkatan, dari yang tidak mampu akhirnya dapat membaca secara lancar, para siswa yang sebelumnya sulit diatur dan dibina, secara evolutif memiliki kesadaran untuk dibimbing dan dibina, terbentuk budaya keagamaan semakin intensif melalui senyum, salam, sapa, pandai bersedekah, santunan kepada kaum dhu'afa mulai ditradisikan, teratur melaksanakan shalat berjamaah. Sedangkan untuk para guru, karyawan dan orang tua, budaya keagamaan yang sering dilaksanakan adalah pengajian agama guru dan karyawan dilaksanakan setiap sepekan sekali, membaca Al-Quran dan dilanjutkan dengan khatmil Quran sebulan sekali secara rutin dan berkesinambungan. Adapun parameter peningkatan pengembangan karakter Rabbani di sekolah, antara lain budaya kejujuran 97\%, budaya kedisiplinan 98\%, santunan kepada kaum dhu'afa dan panti asuhan dilaksanakan sebanyak 3 kali setahun, saling menghargai antara sesama warga sekolah sebesar 97\%, kebersihan dan keindahan sekolah sebesar 95\%, peringatan hari-hari besar Islam setiap tahun dengan capaian target 96\%, dan kerjasama dengan orang tua siswa dalam kaitannya pelaksanaan budaya keagamaan di sekolah dengan capaian target $88 \%$. 


\section{Kesimpulan}

Berdasarkan uraian terdahulu, maka penelitian ini menyimpulkan, sebagai berikut:

1. Karakter secara normatif bermakna watak atau budi pekerti. Budi pekerti adalah bersatunya antara gerakan, fikiran dan perasaan dan kehendak atau kemauan yang kemudian menimbulkan tenaga. Karakter adalah sebagai sifatnya manusia, mulai dari angan-angan hingga terjelma menjadi tenaga. Dengan budi pekerti, manusia akan menjadi pribadi yang merdeka sekaligus berkepribadian mulia dan dapat mengendalikan diri sendiri. Dengan demikian karakter Rabbani adalah karakter Rabbani adalah sebuah aktivitas yang menekankan fungsionalisasi sifat-sifat ketuhanan dalam proses pembelajaran melalui nilai-nilai spiritual, kejujuran, keikhlasan, kasih sayang, toleran, disiplin, kerja keras, kreatif, mandiri, demokratis, komunikatif dan lebih mengutamakan penekanan pada aspek afektif (hati). Karena pendidikan menekankan pada locus hati, meniscayakan munculnya pengembangan nilai-nilai sikap, etika, kepercayaan, perasaan dan moralAdapun kecerdasan spiritual adalah kecerdasan untuk menghadapi persoalan makna (value) yaitu kecerdasan untuk menempatkan perilaku dan hidup seseorang dalam kontek makna yang lebih luas dan kaya. Spiritual Quotient adalah landasan yang diperlukan untuk memfungsikan Intelligence Quotient dan Emotional Quotient secara efektif. Seseorang yang memiliki kecerdasan spiritual memiliki kepribadian yang bertumpu pada nilai-nilai insaniah kemanusiaan yang memancarkan cahaya ruhiah yang menerangi sikap dan tingkah lakunya maupun perbuatannya sehingaga tampil sebagai manusia hanif (lurus), optimis dan konsisten dan bermanfaat bagi lingkungan sekitarnya.

2. Strategi untuk membudayakan nilai-nilai karakter Rabbani pada lembaga pendidikan dapat dilakukan melalui, Pertama, power strategi, yaitu strategi pembudayakan agama di lembaga pendidikan dengan cara meggunakan kekuasaan atau melalui pertama, people's power. People power. Kedua, yakni persuasive strategi dan Ketiga, yakni normative reducative. Ketiga strategi dapat diterapkan melalui metode, sebagai berikut 1) penciptaan suasana religius, yakni dengan mengkondisikan suasana sekolah dengan nilai-nilai dan perilaku religius (keberagamaan). Hal tersebut dapat dilaksanakan dengan cara: a) kepemimpinan, b) skenario penciptaan suasana religius, c) wahana peribadatan, d) dukungan warga masyarakat. (2) internalisasi nilai, yakni dengan memberikan pemahaman dengan agama ke- 
pada siswa, terutama tentang tanggung jawab manusia sebagai pemimpin yang harus arif dan bijaksana, selai itu mereka juga diharapkan memiliki pemahaman Islam yang inklusif dan tidak ekstrim yang menyebabkan islam menjadi agama yang eksklusif. (3) keteladanan, karena merupakan faktor mutlak yang harus dimiliki oleh guru.

3. Penerapan pendidikan karakter Rabbani untuk menumbuhkan kecerdasan spiritual di Sekolah Dasar Islam Terpadu (SDIT) Insani Madani Kota Palopo, adalah melalui upaya pengembangan kurikulum pendidikan agama, membiasakan nilainilai Islami dalam proses pembelajaran, menciptakan lingkungan sekolah yang bersih, dan mengembangkan kedisiplinan yang sesuai dengan nilai-nilai ajaran Islam. 


\section{Daftar Pustaka}

Ahmad, Abu Husain bin Faris Ibn Zakariyyah, 1972. Mu'jam al-Maqayis al-Lughah, Mesir:Musthafa al-Babi al-Halabiy wa Syarikah.

Ahmad, Abu Ali ibn Muhammad ibn Ya'qub Ibn Miskawaih, 1398H. Tahzib al-Akhlaq wa Tathir al-A'raq, Cet. II; Beirut : Mansyurah Dar al- Maktabah al-Hayah.

Amri, Sofan dan Iif Khoiru Ahmadi, 2010. Konstruksi Pengembangan Pembelajaran, Cet. II; Jakarta: Prestasi Pustaka.

Azizi, A. Qodri. 2003. Melawan Globalisasi: Reinterpretasi Ajaran Isla Cet. I; Yogyakarta: Pustaka Pelajar.

Azra, Azyumardi. 1999. Pendidikan Islam: Tradisi dan Modernisasi Menuju Milenium Baru, Cet. II; Jakarta: Logos wacana Ilmu. , 2002. Paradigma Baru Pendidikan Nasional, Cet. I; Jakarta : Kompas.

Barth, Roland S. 2002. Learning by Heart, San Franscisco: Jossey-Bass.

Broadbent, Lynne dan $\quad$ Alan Brown, 2002. Issues in Religious Education New York: Routledge Farmer.

Capra, F. 1994. The Turning Point: Science, Society, and the Rising Culture, New York: Bantam.

Davidson, Matthew and Thomas Lickona, 2006. "Integrating Excellence and Ethics in Character Education" Jurnal Social Science Docket, Vol. 3, No. 7.

Giddens, A. 1990. the Consequences of Modernity, Cambridge: Polity Press.

Goleman, Daniel. 1995. Emotional Intelligence: Why It Can Matter More Than IQ London: Bloomsbury.

Helmy, Masdar. 2008. Islam Profetik: Substansiasi Nilai-Nilai Agama di Ruang Publik, Cet.I; Yogyakarta: Kanisius.

Lickona, Thomas dan Kevin Ryan, 1979. Character Development in School and Beyond, Cardinal, Wasington D.C.

, 1993. "The Return of Character Education," Journal of Educational Leadership, Vol.3, No.3 
, 2013. Pendidikan Karakter: Panduan Lengkap Mendidik Siswa Menjadi Pintar dan Baik, Cet. I; Bandung: Nusa Media.

Lubis, M. Solly. 1997. Umat Islam dalam Globalisasi, Cet. I; Jakarta: Gema Insani Press.

Muhaimin, 2009. Pengembangan Kurikulum Pendidikan Agama Islam: di Sekolah, Madrasah dan Perguruan Tinggi, Cet. I; Jakarta: Raja Grafindo Persada.

Muniz, Jose Luis Martinez Lopes, et. al, 2006. Religious Education in Public Schools: Study of Comparative Law, The Netherland: Springer.

Pasiak, Taufiq. 2003. Revolusi IQ/ EQ/, SQ: Antara Neurosains dan al-Qur'an, Cet. I; Bandung: Mizan.

Sanjaya, Wina. 2010. Strategi Pembelajaran Berorientasi Standar Proses Pendidikan, Cet. II; Jakarta: Prenada Media Group.

Sulaiman, Umar. 2017. Korupsi dan Dialektika Kebahagiaan, Cet. I; Kuningan: Nusa Litera Inspirasi.

Zohar, D dan Ian Marshal, 2000. SQ: Spiritual Intelligence: the Ultimate Intelligence, Great Britain: Bloomsbury. 